\title{
Teleconsultation in the prevention and control of older persons' health with regard to the COVID-19 pandemic: study protocol
}

\section{Teleconsulta para prevenção e controle da saúde do idoso frente à pandemia de COVID-19: protocolo do estudo}

\author{
Vanessa de Lima Silva ${ }^{a}$ (D), Carla Helena Augustin Schwanke ${ }^{\mathrm{b}}$, \\ Adriana Falangola Benjamin Bezerra ${ }^{a}\left(\mathbb{D}\right.$, Ana Paula de Oliveira Marques ${ }^{a}$ (D), \\ Tatiana de Paula Santana da Silva ${ }^{\circledR}$ (D), Carla Cabral dos Santos Accioly Lins ${ }^{a}$ (1), \\ Maria Lúcia Gurgel da Costa ${ }^{a}$ (D), Anna Karla de Oliveira Tito Borba ${ }^{a}$ (D), \\ IIma Kruze Grande de Arruda ${ }^{a}$ (D), Maria das Graças Wanderley de Sales Coriolano ${ }^{a}$
}

\begin{abstract}
OBJECTIVE: To report the following study protocol: "Prevention program for older persons' health care focusing on the COVID-19 pandemic in the city of Recife - PE." METHODS: An action research study will be conducted with 151 older people of both sexes residing in the 8 health districts of Recife, Brazil. A teleconsultation service will be used to converse with participants. Activities will be organized into 2 moments: diagnosis and intervention. A guided conversation strategy will be used, dealing with issues related to coronavirus disease 2019 (COVID-19) prevention; social isolation; thoughts, emotions, and spirituality; family and community support; and personal development and ground rules for everyday life. The intervention with each older person will happen weekly for 12 weeks and will be characterized by listening to them and exchanging knowledge with the aim of bonding and optimizing adherence and compliance to COVID-19 prevention and control measures. Our data analysis will follow 3 approaches: cross-sectional (multivariate regression model), quasi-experimental (analysis of standardized residuals), and qualitative (interview and content analysis). EXPECTED RESULTS AND RELEVANCE: The construction of scientific knowledge is a key strategy when faced with the great challenge to global collective health presented by the COVID-19 pandemic. Data generated in this study may contribute to the improvement of knowledge, attitudes, and preventive practices, as well as to a good acceptance of the prevention program by older participants.
\end{abstract}

KEYWORDS: aged, disease prevention, primary health care, remote consultation, coronavirus infections.

aniversidade Federal de Pernambuco - Recife (PE), Brazil.

bPontifícia Universidade Católica do Rio Grande do Sul - Porto Alegre (RS), Brazil.

'Secretaria Estadual de Saúde de Pernambuco - Recife (PE), Brazil.

Correspondence data

Vanessa de Lima Silva - Programa de Pós-Graduação em Gerontologia, Universidade Federal de Pernambuco - Av. Prof. Moraes Rego, S/N Cidade Universitária - CEP: 50739-970 - Recife (PE), Brazil. E-mail: vanessa.silva@ufpe.br @limavanes

Received on: 06/11/2021. Accepted on: 09/04/2021

How to cite this article: Silva VL, Schwanke CHA, Bezerra AFB, Marques APO, TPS Silva, Lins CCSA, et al. Teleconsultation in the prevention and control of older persons' health with regard to the COVID-19 pandemic: study protocol. Geriatr Gerontol Aging. 2021;15:e0210047. https://doi.org/10.53886/gga.E0210047

https://doi.org/10.53886/gga.E0210047 


\begin{abstract}
OBJETIVO: Apresentar o protocolo "Programa de prevenção para a saúde do idoso com foco na pandemia de COVID-19 no município do Recife - PE”. METODOLOGIA: Um estudo de pesquisa-ação será conduzido com 151 idosos de ambos os sexos que residem nos 8 distritos sanitários de Recife, Brasil. Um serviço de teleconsulta será usado para comunicação com os participantes. As atividades serão organizadas em 2 momentos: diagnóstico e intervenção. Uma estratégia de conversa guiada será adotada para com os idosos, tratando de temas relacionados à prevenção de COVID-19; isolamento social; pensamentos, emoções e espiritualidade; família e suporte comunitário; desenvolvimento pessoal; e regras básicas para o cotidiano. A intervenção com cada idoso ocorrerá uma vez por semana por 12 semanas, sendo caracterizada pela escuta e troca de conhecimentos com o objetivo de gerar um vínculo e otimizar a aderência e observância de medidas de prevenção e controle de COVID-19. A análise de dados seguirá 3 abordagens: transversal (modelo de regressão multivariada), quase-experimental (análise de resíduos padronizados), e qualitativa (entrevista e análise de conteúdo). RESULTADOS ESPERADOS E RELEVÂNCIA: A construção do conhecimento científico é uma estratégia chave frente ao grande desafio para a saúde coletiva global representado pela pandemia de COVID-19. Dados gerados por este estudo podem contribuir para a melhoria do conhecimento, atitudes, e medidas de prevenção, além de uma boa aceitação do programa de prevenção por parte dos participantes idosos.
\end{abstract}

PALAVRAS-CHAVE: idoso, prevenção de doenças, atenção primária à saúde, consulta remota, infecções por coronavírus.

\section{INTRODUCTION}

The older population stands out when considering priority groups for coronavirus disease 2019 (COVID-19) prevention and combat strategies. In general, this group has a less favorable outcome in terms of disease progression. The mortality and proportion of patients with severe pneumonia are significantly higher in the older population than in middle-aged and younger individuals. ${ }^{1}$

The construction of a care model for the older population is an important challenge for health care systems, ${ }^{2}$ given circumstances that involve providing health care for this group while ensuring that virus transmission is blocked. The epidemiological profile of this population is characterized by chronic diseases requiring continuous care, thus being a highly vulnerable group to the effects of social distancing, which is an important means of preventing COVID-19.

The presence of frailty and comorbidity in this population can result in longer hospital stays and the need for more intensive care, which makes prevention and control strategies against the spread of the virus even more relevant.

The use of telehealth as an intervention strategy for older persons, such as teleconsultation, minimizes the impact of social distancing measures adopted during the pandemic. Moreover, it reduces geographic barriers and eliminates the risk of contamination presented by face-to-face care while offering a safe service.

The research problem under consideration is the greater vulnerability of the older population in the context of the COVID-19 pandemic, having an increased probability of progressing to a severe form of the disease, requiring the use of intensive care resources for longer periods, and having a greater chance of death. This scenario places this group as a priority for infection prevention and control strategies.

The present article describes the methods used in the research titled "Prevention program for older persons' health care focusing on the COVID-19 pandemic in the city of Recife - PE." The study involves 3 sub-projects focused on: (1) the analysis of factors associated with knowledge, attitudes, and preventive practices related to COVID-19 and of difficulties and barriers to maintaining social isolation in the older population (a cross-sectional study); (2) the analysis of the effect of a teleconsultation program on prevention and control considering knowledge, attitudes, and preventive practices related to COVID-19 and difficulties and barriers to maintaining social isolation (a quasi-experimental study); (3) the analysis of the satisfaction of older participants considering the prevention program (a qualitative study).

\section{METHODS}

\section{Study design}

A mixed methods (qualitative and quantitative) research approach will be adopted. Cross-sectional, quasi-experimental, and qualitative designs will be used for the development of subprojects to encompass this study.

The construction of the teleconsultation program for preventing and controlling COVID-19 considering older persons' health in the city of Recife - PE will follow an action research design, ${ }^{3}$ using evidence-informed health policymaking $^{4}$ and situational strategic planning as its basis. ${ }^{5}$ 


\section{Population and sample}

The project will be conducted in all 8 health districts of Recife. Eight teleconsultants will be contemplated, each with the capacity for weekly consultations with 20 older people, with the final aim of reaching 160 participants. Therefore, the sample size and sampling process for the present study will be defined by convenience, the ability to recruit qualified teleconsultants, and agreement with the city's health management division.

\section{Recruitment}

The criteria for participation in the $60+$ at home - COVID19 program will be: individuals aged 60 years or over, of both sexes, residing in one of the city's health districts, and with access to a computer or mobile telephone with internet access.

The interdisciplinary and interprofessional program will be targeted at the health care needs of the older population of the city of Recife, as reported by health division managers. Meetings will be held with the Municipal Health Department management team for older persons' health care, focusing on the dialogue regarding the health care needs of this population and discussing the available scientific evidence and feasibility of implementation strategies. Subsequent steps will be then defined, together with a schedule for their implementation.

Participant recruitment will be initiated following a strategic analysis together with the municipal team responsible for coordinating older persons' health care, who recommended the target group for the program. Older people cared for by the Municipal Health Department's COVID-19 referral centers will be included in the prevention program, to be conducted via telephone.

\section{Teleconsultation}

A teleconsultation service will be used as a conversation strategy with the older individuals for developing health education actions aimed at preventing COVID-19 and for monitoring their chronic conditions, which increase the risks brought by contamination.

A unified communication and collaboration platform using Microsoft Teams will be used to coordinate teleconsultations via telephone or computer, as it is considered a tool for continuous use by the population. The platform will be made available by the State Telehealth Center of the Pernambuco State Health Department (NET-SES-PE), along with technical support for the training, operation, and management of the application.

This platform enables audio and videoconference calls and file storage with a data confidentiality resource and software integration, meeting all requirements listed in the Health
Insurance Portability and Accountability Act (HIPAA) ${ }^{6}$ protocol. The electronic link for teleconsultation will be sent to the participant via WhatsApp. Calls were made by experienced members of the multidisciplinary health care team.

\section{Activity}

The teleconsultation activity for COVID-19 prevention and control will be conducted with each participant on a weekly basis, for 12 weeks. Each virtual meeting will last between 30 minutes and 1 hour and involved listening to and exchanging information with the participant. The program strategy will aim to build a relationship and optimize adherence and compliance with COVID-19 prevention and control measures.

Each teleconsultation will be organized in 2 stages: (1) diagnosis (epidemiological survey and knowledge, attitude, and practices [KAP] survey); and (2) intervention (COVID19 prevention actions) (Table 1 ).

Semi-structured research instruments will be used at the time of diagnosis (baseline): a) a COVID-19 screening instrument - comprising items related to virus infection according to the literature; b) a sociodemographic survey; $c$ ) a health conditions questionnaire; d) the Lawton Scale Instrumental Activities of Daily Living; ${ }^{7}$ e) family and community functioning assessment; f) a cognitive screening; $g$ ) the Geriatric Depression Scale $;^{8} \mathrm{~h}$ ) the Trait Anxiety Scale; i) the ASHA FACS protocol - communication independence; $^{9}$ and $\mathrm{j}$ ) a survey on COVID-19 knowledge, attitude, and preventive practices in addition to difficulties and barriers to maintaining social isolation in the older population. The KAP survey was chosen for this end and will serve as basis for COVID-19 prevention and control activities. Finally, k) a questionnaire on difficulties and barriers to maintaining prevention attitudes (Table 2).

The COVID-19 screening instrument will be applied at the beginning of each intervention. Participants with a score equal to or greater than 9 in this instrument will be referred to the Family Health Unit or COVID-19 referral service. Data collection will be performed online by teleconsultants at the moment of the activity using Google Forms software.

The intervention will focus on COVID-19 prevention and control activities among the participants. These actions will be planned according to the needs identified at diagnosis and the themes proposed by the "Healthy Aging in Times of Pandemic - LabEduca60 + Guidelines" booklet. ${ }^{10}$

A guided conversation strategy will be adopted, in which participants received information and shared their knowledge, concerns, and strategies for dealing with the COVID-19 pandemic. 
The following themes will be addressed: COVID-19 the new coronavirus - concept, origin, and means of transmission; social isolation - its importance and how older people are coping; preventive behaviors - attitudes aiming to prevent infection; thoughts, emotions and spirituality - emotional support strategies; family and community support - importance and strategies; personal development - strategies for occupational activities; basic rules for everyday life; balanced diet; physical activities and exercises; and creativity, leisure, and new experiences. Lastly, strategies were defined for the continuity of COVID-19 prevention activities in the participants' weekly routines, and the program was evaluated.
The diagnosis and intervention moments will occur at each virtual meeting with the individual, according to the addressed theme. At the end of the 12-week intervention period, the survey on knowledge, attitudes, and preventive practices related to COVID-19 in addition to difficulties and barriers to maintaining social isolation in the older population will be reapplied, with the results being considered an outcome of this action research initiative.

\section{Ethical considerations}

This research was approved by the Human Research Ethics Committee of the Health Sciences Center of Universidade

Table 1. Activities performed in the prevention program for older persons' health care focusing on the COVID-19 pandemic in the city of Recife, PE.

\begin{tabular}{|c|c|c|}
\hline \multirow{2}{*}{ Day } & \multicolumn{2}{|c|}{ Activity } \\
\hline & Diagnosis/instrument & Prevention action/theme to be addressed* \\
\hline 1 & $\begin{array}{l}\text { Presentation of the research and informed consent } \\
\text { KAP survey } \\
\text { COVID-19 screening }\end{array}$ & $\begin{array}{l}\text { Listening and knowledge exchange } \\
\text { The new coronavirus }\end{array}$ \\
\hline 2 & $\begin{array}{l}\text { COVID-19 screening } \\
\text { Sociodemographic questionnaire } \\
\text { Cognitive screening } \\
\text { Health conditions questionnaire }\end{array}$ & $\begin{array}{l}\text { Listening and knowledge exchange } \\
\text { Social isolation } \\
\text { How to deal with social isolation? }\end{array}$ \\
\hline 3 & $\begin{array}{l}\text { COVID-19 screening } \\
\text { Evaluation of family and community functioning }\end{array}$ & $\begin{array}{l}\text { Listening and knowledge exchange } \\
\text { Family and community support }\end{array}$ \\
\hline 4 & $\begin{array}{l}\text { COVID-19 screening } \\
\text { Evaluation of depression symptoms (GDS) }\end{array}$ & $\begin{array}{l}\text { Listening and knowledge exchange } \\
\text { Thoughts, emotions, behaviors, and spirituality }\end{array}$ \\
\hline 5 & $\begin{array}{l}\text { COVID-19 screening } \\
\text { Evaluation of anxiety }\end{array}$ & $\begin{array}{l}\text { Listening and knowledge exchange } \\
\text { Thoughts, emotions, behaviors, and spirituality }\end{array}$ \\
\hline 6 & $\begin{array}{l}\text { COVID-19 screening } \\
\text { Assessment of communication independence } \\
\text { (ASHA FACS - domain 1) }\end{array}$ & $\begin{array}{l}\text { Listening and knowledge exchange } \\
\text { Personal development }\end{array}$ \\
\hline 7 & $\begin{array}{l}\text { COVID-19 screening } \\
\text { Assessment of communication independence } \\
\text { (ASHA FACS - domains } 2 \text { to } 4 \text { ) }\end{array}$ & $\begin{array}{l}\text { Listening and knowledge exchange } \\
\text { Preventive behaviors }\end{array}$ \\
\hline 8 & $\begin{array}{c}\text { COVID-19 screening } \\
\text { Evaluation of Instrumental Activities of Daily Living } \\
\text { (Lawton and Brody scale) }\end{array}$ & $\begin{array}{l}\text { Listening and knowledge exchange } \\
\text { Basic rules for everyday life }\end{array}$ \\
\hline 9 & COVID-19 screening & $\begin{array}{l}\text { Listening and knowledge exchange } \\
\text { Balanced diet }\end{array}$ \\
\hline 10 & COVID-19 screening & $\begin{array}{l}\text { Listening and knowledge exchange } \\
\text { Physical activities and exercise }\end{array}$ \\
\hline 11 & COVID-19 screening & $\begin{array}{l}\text { Listening and knowledge exchange } \\
\text { Creativity, leisure, and new experiences Incorporation of } \\
\text { preventive measures into the daily routine }\end{array}$ \\
\hline 12 & $\begin{array}{l}\text { COVID-19 screening } \\
\text { KAP survey }\end{array}$ & Program evaluation \\
\hline
\end{tabular}

*Themes proposed by the "Healthy aging in times of pandemic — LabEduca60+ Guidelines" booklet. ${ }^{10}$ KAP: Knowledge, Attitude, and Practices; COVID-19: coronavirus disease 2019; GDS: Geriatric Depression Scale; ASHA FACS: American Speech-Language-Hearing Association Functional Assessment of Communication Skills for Adults. 
Table 2. Instruments to be used for data collection.

\begin{tabular}{|c|c|c|c|}
\hline Instrument & Description & Variables & Reference \\
\hline $\begin{array}{l}\text { Sociodemographic } \\
\text { questionnaire }\end{array}$ & $\begin{array}{l}\text { Survey of sociodemographic and } \\
\text { economic data }\end{array}$ & $\begin{array}{l}\text { Sex, age, marital status, race/ } \\
\text { skin color, family income, } \\
\text { occupation, literacy, education }\end{array}$ & Prepared by the authors \\
\hline KAP survey & $\begin{array}{l}\text { Knowledge, attitudes, and preventive } \\
\text { practices related to COVID-19 }\end{array}$ & $\begin{array}{l}\text { Knowledge: COVID-19, means of } \\
\text { information, recommendations } \\
\text { for prevention, purpose } \\
\text { of prevention. } \\
\text { Attitude: agreement with } \\
\text { recommendations, opinion on } \\
\text { recommendations. } \\
\text { Practice: frequency of } \\
\text { preventive measures, frequency } \\
\text { of leaving home, mask use, } \\
\text { hand washing, respiratory } \\
\text { etiquette, isolating at home } \\
\text { after contact with the virus. }\end{array}$ & Prepared by the authors \\
\hline $\begin{array}{l}\text { Instrument: difficulties } \\
\text { and barriers } \\
\text { to maintaining } \\
\text { preventive attitudes }\end{array}$ & $\begin{array}{l}\text { Difficulties and barriers to complying } \\
\text { with recommendations for } \\
\text { COVID-19 prevention }\end{array}$ & $\begin{array}{l}\text { Difficulty in hand washing, } \\
\text { difficulty with respiratory } \\
\text { etiquette, difficulty in using a } \\
\text { mask, difficulty staying at home, } \\
\text { difficulty in isolating at home } \\
\text { after contact with the virus }\end{array}$ & Prepared by the authors \\
\hline $\begin{array}{l}\text { COVID-19 screening } \\
\text { instrument }\end{array}$ & $\begin{array}{l}\text { Items related to virus infection according } \\
\text { to the literature: fever, headache, runny } \\
\text { nose or sneezing, throat pain/irritation, dry } \\
\text { cough, difficulty breathing, body aches, } \\
\text { diarrhea, travel in the previous } 14 \text { days } \\
\text { to somewhere with confirmed COVID-19 } \\
\text { cases, contact in the previous } 14 \text { days } \\
\text { with any confirmed COVID-19 case, loss of } \\
\text { smell, loss of taste } \\
1-9 \text { = low risk } \\
10-19=\text { moderate risk } \\
20-36 \text { = high risk }\end{array}$ & Risk of COVID-19 & $\begin{array}{l}\text { Prepared by the } \\
\text { authors (based on the } \\
\text { Mozambique Telehealth } \\
\text { Risk Self-assessment) }{ }^{12}\end{array}$ \\
\hline Cognitive screening & $\begin{array}{l}\text { Answer } 3 \text { questions: } \\
\text { 1) Has a family member or friend told you } \\
\text { that you are becoming forgetful? } \\
\text { 2) Has the forgetfulness become worse in } \\
\text { the recent months? } \\
\text { 3) Is the forgetfulness preventing you } \\
\text { from performing some daily activities? } \\
\text { Yes to any of the questions = indicative of } \\
\text { cognitive decline }\end{array}$ & Indication of cognitive decline & $\begin{array}{l}\text { The Older Person's } \\
\text { Health Booklet }{ }^{13}\end{array}$ \\
\hline $\begin{array}{l}\text { Health conditions } \\
\text { questionnaire }\end{array}$ & $\begin{array}{l}\text { Survey of the main self- } \\
\text { reported morbidities }\end{array}$ & $\begin{array}{l}\text { Hypertension, diabetes mellitus, } \\
\text { cardiovascular disease, } \\
\text { osteoporosis, osteoarthrosis, } \\
\text { neurological disease, } \\
\text { cancer, arbovirus infection, } \\
\text { smoking, alcoholism }\end{array}$ & Prepared by the authors \\
\hline Family APGAR & $\begin{array}{l}\text { Assessment instrument designed to reflect } \\
\text { the satisfaction of each family member. } \\
\text { From a predetermined questionnaire, } \\
\text { families are classified as functional or } \\
\text { moderately/severely dysfunctional }\end{array}$ & $\begin{array}{l}\text { Family and community } \\
\text { functioning }\end{array}$ & $\begin{array}{l}\text { Using the family APGAR } \\
\text { score to evaluate } \\
\text { family relationships } \\
\text { in the elderly: an } \\
\text { integrative review }{ }^{14}\end{array}$ \\
\hline
\end{tabular}


Table 2. Continuation.

\begin{tabular}{|c|c|c|c|}
\hline Instrument & Description & Variables & Reference \\
\hline $\begin{array}{l}\text { Geriatric Depression Scale, } \\
\text { short form (GDS - 15) }\end{array}$ & $\begin{array}{l}\text { A } 15 \text {-question short form of the GDS scale } \\
\text { on how a person has been feeling in the } \\
\text { last week } \\
\begin{array}{c}\text { Scores } \geq 6 \text { points are considered indicative } \\
\text { of depression }\end{array}\end{array}$ & Depression symptoms & $\begin{array}{l}\text { Reliability of the } \\
\text { Brazilian version of the } \\
\text { Geriatric Depression } \\
\text { Scale short form }\end{array}$ \\
\hline Trait Anxiety Scale & $\begin{array}{c}\text { Assesses anxiety as a trait (STAI-T). It has } \\
20 \text { items with a score of } 1-4 \text { for each item } \\
\text { Score ranges from } 20 \text { to } 80 \\
\text { Scores }>42 \text { tend toward anxiety and } \\
\text { those }<38 \text { tend toward depression }\end{array}$ & Anxiety & $\begin{array}{l}\text { Manual for the State- } \\
\text { Trait Anxiety Inventory } \\
(\text { STAI) })^{15}\end{array}$ \\
\hline ASHA FACS Protocol & $\begin{array}{l}\text { The questionnaire has } 43 \text { items divided } \\
\text { into } 4 \text { domains: social communication; } \\
\text { communication of basic needs; reading, } \\
\text { writing and numerical concepts; and } \\
\text { daily planning } \\
\text { Seven-point scale: } \\
7 \text { - individual who does not need help to } \\
\text { communicate } \\
1 \text { - needs maximum help }\end{array}$ & Communication independence & $\begin{array}{l}\text { Functional } \\
\text { communication skills: } \\
\text { older persons' health }{ }^{16}\end{array}$ \\
\hline Lawton \& Brody scale & $\begin{array}{l}\text { Evaluates performance in nine activities: } \\
\text { telephone use, shopping, preparing meals, } \\
\text { tidying the house, washing clothes, minor } \\
\text { household repairs, getting around outside } \\
\text { the home, medication responsibility, and } \\
\text { money management } \\
9 \text { points - maximum dependency } \\
27 \text { points - total independence }\end{array}$ & $\begin{array}{l}\text { Independence for Instrumental } \\
\text { Activities of Daily Living }\end{array}$ & $\begin{array}{l}\text { Assessment of older } \\
\text { people: self-maintaining } \\
\text { and instrumental } \\
\text { activities of daily living }{ }^{17}\end{array}$ \\
\hline
\end{tabular}

APGAR: Adaptability, Partnership, Growth, Affection, and Resolve.

Federal de Pernambuco under Certificate of Presentation for Ethical Appreciation (CAAE) number 31829720600005208 (registration No. 4089 705). All older individuals consented to participate in the study through oral consent obtained by telephone contact.

\section{Data storage and analysis}

The collected data will be recorded on a Microsoft Excelbased database. Data analyses will be performed using SPSS software, version 20.

Data analysis will vary according to the specific objective of each subproject (Table 3).

A cross-sectional study design will be adopted for the first subproject, which considers a description of factors associated with knowledge, attitudes, and preventive practices related to COVID-19, in addition to the difficulties and barriers to maintaining social isolation in the older population.
Data analysis will be performed using a multivariate regression model, identifying the effect measure expressed by the odds ratio (OR) and corresponding 95\% confidence inter$\operatorname{val}(95 \% \mathrm{CI})$.

Data from the second subproject, considering an analysis of the effect of the teleconsultation program on COVID-19 prevention and control and covering the knowledge, attitudes, and preventive practices in addition to difficulties and barriers to maintaining social isolation, will be analyzed through a quasi-experimental design. This design is characterized by the analysis of the effect of an intervention in a single comparison group. Descriptive statistics and analysis of standardized residuals will be used to compare the characteristic patterns of each category before and after the intervention.

The third subproject will assess the satisfaction of participants regarding the prevention program for older persons' health care focusing on the COVID-19 pandemic in the city 
of Recife. A qualitative method will be adopted for analysis through an interview to be performed on the last day of the program. The interviews will be transcribed and evaluated through content analysis, as proposed by Bardin, ${ }^{11}$ split into the pre-analysis stages (attentive and floating reading of the transcribed words of the participants); coding of the raw data phase (cut, aggregation, and enumeration); analysis of category themes (identification of core meanings); identification of category themes; and discussion (inferences and interpretations regarding the obtained materials by relating them to the theoretical framework).

\section{RELEVANCE AND DISSEMINATION}

The phenomenon of the COVID-19 pandemic involving older persons' health care and the need to prevent the spread of severe acute respiratory syndrome coronavirus 2 (SARS COV-2) is a very complex situation. Therefore, the availability of a prevention protocol to be applied remotely with the potential to reach large numbers of older people (given the coverage of the national health system) will be of great importance in preserving the health of this population and contributing to their quality of life.

Results of the study will be disseminated in the near future through presentations at conferences on aging and articles to be published in peer-reviewed journals.

\section{CONFLICTS OF INTEREST}

The authors declare that they have no known competing financial interests or personal relationships that could have appeared to influence the work reported in this paper.

Table 3. Subprojects, study design, data collection instruments, and data analysis methods.

\begin{tabular}{|c|c|c|c|}
\hline Subproject & Study design & Data collection instruments & Data analysis methods \\
\hline $\begin{array}{l}\text { 1- Factors associated with } \\
\text { knowledge, attitudes, and } \\
\text { preventive practices related to } \\
\text { COVID-19, and difficulties and } \\
\text { barriers to maintaining social } \\
\text { isolation in the older population }\end{array}$ & Cross-sectional & $\begin{array}{l}\text { - Knowledge, Attitude, and } \\
\text { Practices (KAP) survey for } \\
\text { COVID-19 prevention } \\
\text { - Difficulties and barriers to } \\
\text { maintaining preventive attitudes } \\
\text { - COVID-19 screening instrument } \\
\text { - Sociodemographic survey } \\
\text { - Cognitive screening } \\
\text { - Health conditions } \\
\text { - Family and community } \\
\text { functioning } \\
\text { - Geriatric Depression Scale } \\
\text { - Trait Anxiety Scale } \\
\text { - ASHA FACS Protocol } \\
\text { - Lawton Scale }\end{array}$ & $\begin{array}{l}\text { Multivariate regression model, } \\
\text { estimating the odds ratio and } \\
\text { corresponding } 95 \% \text { confidence interval } \\
\text { as an effect measure }\end{array}$ \\
\hline $\begin{array}{l}\text { 2- Analysis of the effect of } \\
\text { the teleconsultation program } \\
\text { on COVID-19 prevention and } \\
\text { control considering knowledge, } \\
\text { attitudes, and preventive } \\
\text { practices in addition to } \\
\text { difficulties and barriers to } \\
\text { maintaining social isolation }\end{array}$ & $\begin{array}{c}\text { Quasi- } \\
\text { experimental }\end{array}$ & $\begin{array}{l}\text { - KAP survey for COVID-19 } \\
\text { prevention } \\
\text { - Difficulties and barriers to } \\
\text { maintaining preventive attitudes }\end{array}$ & $\begin{array}{l}\text { Descriptive statistics and analysis of } \\
\text { standardized residuals to compare } \\
\text { characteristic patterns of each category } \\
\text { before and after the intervention }\end{array}$ \\
\hline $\begin{array}{l}\text { 3- Satisfaction of the } \\
\text { participants regarding the } \\
\text { prevention program for older } \\
\text { persons' health care focusing } \\
\text { on the COVID-19 pandemic in } \\
\text { the city of Recife }\end{array}$ & $\begin{array}{l}\text { Qualitative } \\
\text { study }\end{array}$ & $\begin{array}{l}\text { End of program interview covering } \\
\text { the following themes: } \\
\text { - Program evaluation; } \\
\text { - Participant satisfaction; } \\
\text { - Contribution of the program to } \\
\text { health care; } \\
\text { - Suggestions for improvement }\end{array}$ & $\begin{array}{l}\text { Interview and content analysis, split } \\
\text { into pre-analysis stages (cursory and } \\
\text { attentive reading of the participants' } \\
\text { transcribed words); coding of the } \\
\text { raw data (cut, aggregation, and } \\
\text { enumeration); analysis of category } \\
\text { themes (identification of core } \\
\text { meanings); identification of category } \\
\text { themes; and discussion (inferences and } \\
\text { interpretations regarding the obtained } \\
\text { materials by relating them to the } \\
\text { theoretical framework) }\end{array}$ \\
\hline
\end{tabular}




\section{FUNDING}

This study is supported by the Office of the Dean for Research at Universidade Federal de Pernambuco, protocol No. 23076 019568/2020-90.

\section{AUTHORS' CONTRIBUTIONS}

VLS: conceptualization, data curation, methodology, project administration, writing - review \& editing.
CHAS: conceptualization, methodology, writing - review \& editing. AFBB: methodology, writing - review \& editing, supervision. APOM: methodology, writing - review \& editing, supervision. TPSS: methodology, writing review \& editing. CCSAL: writing - review \& editing. MLGC: writing - review \& editing. AKOTB: writing review \& editing. IKGA: writing - review \& editing. MGWSC: conceptualization, methodology, writing review \& editing.

\section{REFERENCES}

1. Liu K, Chen Y, Lin R, Han K. Clinical features of COVID-19 in elderly patients: A comparison with young and middle-aged patients. Infect. 2020;80(6):e14-8. https://doi.org/10.1016/j.jinf.2020.03.005

2. Veras RP, O modelo assistencial contemporâneo e inovador para os idosos. Rev Bras Geriatr Gerontol. 2020;23(1):e200061. https:// doi.org/10.1590/1981-22562020023.200061

3. Thiollent M. Metodologia da Pesquisa-Ação. 18th. ed. São Paulo: Cortez; 2011.

4. Ramos MC, Silva EN. Como usar a abordagem da Política Informada por Evidência na saúde pública? Saúde Debate. 2018;42(116):296306. https://doi.org/10.1590/0103-1104201811624

5. Rivera FJU, Testa M, Matus C. Planejamento e programação em saúde - um enfoque estratégico. São Paulo: Cortez; 1989.

6. U.S. Department of Health \& Human Services. Office for Civil Rights Headquarters. Protocol Health Insurance Portability and Accountability Act (HIPAA). Washington, D.C.: OCR; 2021.

7. Santos RL, Virtuoso Junior JS. Reliability of the Brazilian version of the Scale 313 of Instrumental Activities of Daily Living. Rev Bras Promoç Saúde. 2008;21(4):290-6.

8. Almeida OP, Almeida SA. Confiabilidade da versão brasileira da Escala de Depressão Geriátrica (GDS) versão reduzida. Arq NeuroPsiquiatr. 1999;57(2)-B:421-6. https://doi.org/10.1590/S0004282X1999000300013
9. Carvalho IAM, Mansur L. Avaliação funcional das habilidades de comunicação: ASHA FACS para população com Doença de Alzheimer [tese]. São Paulo: FMUSP; 2006.

10. LABEDUCA60+USP. Cartilha Envelhecimento saudável em tempos de Pandemia - Orientações do LabEduca60+. São Paulo: USP; 2020.

11. Bardin L. Análise de Conteúdo. São Paulo: Edições 70; 2011.

12. Ministério da Saúde de Moçambique. Telessaúde de Moçambique. Auto-avaliação de risco. Available from: https://riscocovid 19.misau. gov.mz/. Accessed in Sep 10, 2020.

13. Ministério da Saúde do Brasil. Caderneta de Saúde da Pessoa Idosa. 3rd. ed. Brasília: Ministério da Saúde; 2014.

14. Vera I, Lucchese R, Munari DB, Nakatani AYK. Índex APGAR de Família na avaliação de relações familiares do idoso: revisão integrativa. Rev Eletr Énferm. 2014;16(1):199-210. https://doi.org/10.5216/ree. v16i1.22514

15. Biaggio AMB, Natalício L. Manual para o Inventário de Ansiedade Traço-Estado (IDATE). Rio de Janeiro: Centro Editor de Psicologia Aplicada-CEPA; 1979.

16. Garcia FHA, Mansur LL. Habilidades funcionais de comunicação: idoso saudável. Acta Fisiatr. 2006;13(2):87-9.

17. Lawton MP, Brody EM. Assessment of older people: self-maintaining and instrumental activities of daily living. Gerontologist. 1969;9(3):179-86. 